\title{
Absence of nuclease activity in commonly used oxygen-scavenging systems
}

\author{
Hailey L. Gahlon ${ }^{1,2}$, Paul Poudevigne-Durance ${ }^{1,2}$ and David Rueda ${ }^{1,2^{*}}$ (D)
}

\begin{abstract}
Objective: Oxygen scavenging systems are routinely used during single-molecule imaging experiments to improve fluorescent dye stability. Previous work has shown nuclease contamination in the commonly used oxygen scavenging systems. This study evaluates the potential for nuclease contamination in these oxygen scavenging systems.

Results: Linear and plasmid DNA was incubated with two different oxygen scavenging systems (1) protocatechuic acid (PCA)-protocatechuate-3,4-dioxygenase (PCD) and (2) glucose-coupled glucose oxidase/catalase (GODCAT). No nucleic acid degradation was observed on single and double-stranded linear DNA and plasmid DNA, indicating the absence of nuclease contamination in these oxygen scavenging systems.
\end{abstract}

Keywords: Single-molecule imaging, Oxygen scavenging system, Protocatechuate-3,4-dioxygenase, Protocatechuic acid, Glucose oxidase, Catalase

\section{Introduction}

Previous work has suggested that contaminant nuclease enzymes could be affecting single-molecule studies [1]. Using size-exclusion chromatography, this study reported the presence of nuclease contamination in the 40- and $100 \mathrm{kDa}$ elution fractions of routinely used OSS system with protocatechuic acid (PCA)-protocatechuate-3,4-dioxygenase (PCD), with the $40 \mathrm{kDa}$ fraction exhibiting the highest nuclease activity. Such contamination could compromise DNA integrity during a single-molecule experiment, leading to false or inaccurate data interpretation. Therefore, we decided to test if we can observe similar DNA degradation on linear single- and double-stranded DNA constructs as well as circular plasmid DNA in the presence of the commonly used OSS systems, (PCA)(PCD) and glucose-coupled glucose oxidase/catalase (GODCAT).

\section{Main text \\ Methods \\ Linear DNA substrates}

Linear DNA sequences include the 92-mer strand, $5^{\prime}$-CCC TAC ATC CAT TCC TCG CGT TTT TT(Cy3-T) (T) ${ }_{65}-3^{\prime}$, the single-stranded 66-mer, $5^{\prime}$-Cy3 ACC TCC TCA CCT TTC CTC TTT GCT TTC CCC TTT TCT ACA ATA CGG ATA CGG ACG GCT GCA TCT CTG- ${ }^{\prime}$ and the 66-mer double-stranded DNA that contains a complementary 66-mer sequence annealed to the above mentioned 66-mer sequence with a $5^{\prime}$ biotin. DNA oligonucleotides were purchased from Eurofins Genomics.

\section{Plasmid DNA substrates}

Double-stranded circular pUC19 plasmid DNA (2686 bp) was tested for potential nuclease contamination. Plasmid DNA was purchased from Invitrogen.

\section{Nuclease assay}

Each reaction contained $0.01 \mathrm{nmol}$ of Cy3 DNA, except for the double-stranded DNA reactions (Fig. 1a, lanes $7-8$ ) that contained $0.01 \mathrm{nmol}$ of Cy3 DNA and $0.01 \mathrm{nmol}$ of the complementary DNA strand. Concentrations for each specified reaction are as follows, $60 \mathrm{nM}$ protocatechuate-3,4-dioxygenase (PCD) (accounting for the 40\%

\footnotetext{
${ }^{*}$ Correspondence: david.rueda@imperial.ac.uk
Molecular Virology, Department of Medicine, Imperial College London,

Du Cane Road, London W12 0NN, UK

Full list of author information is available at the end of the article
} 


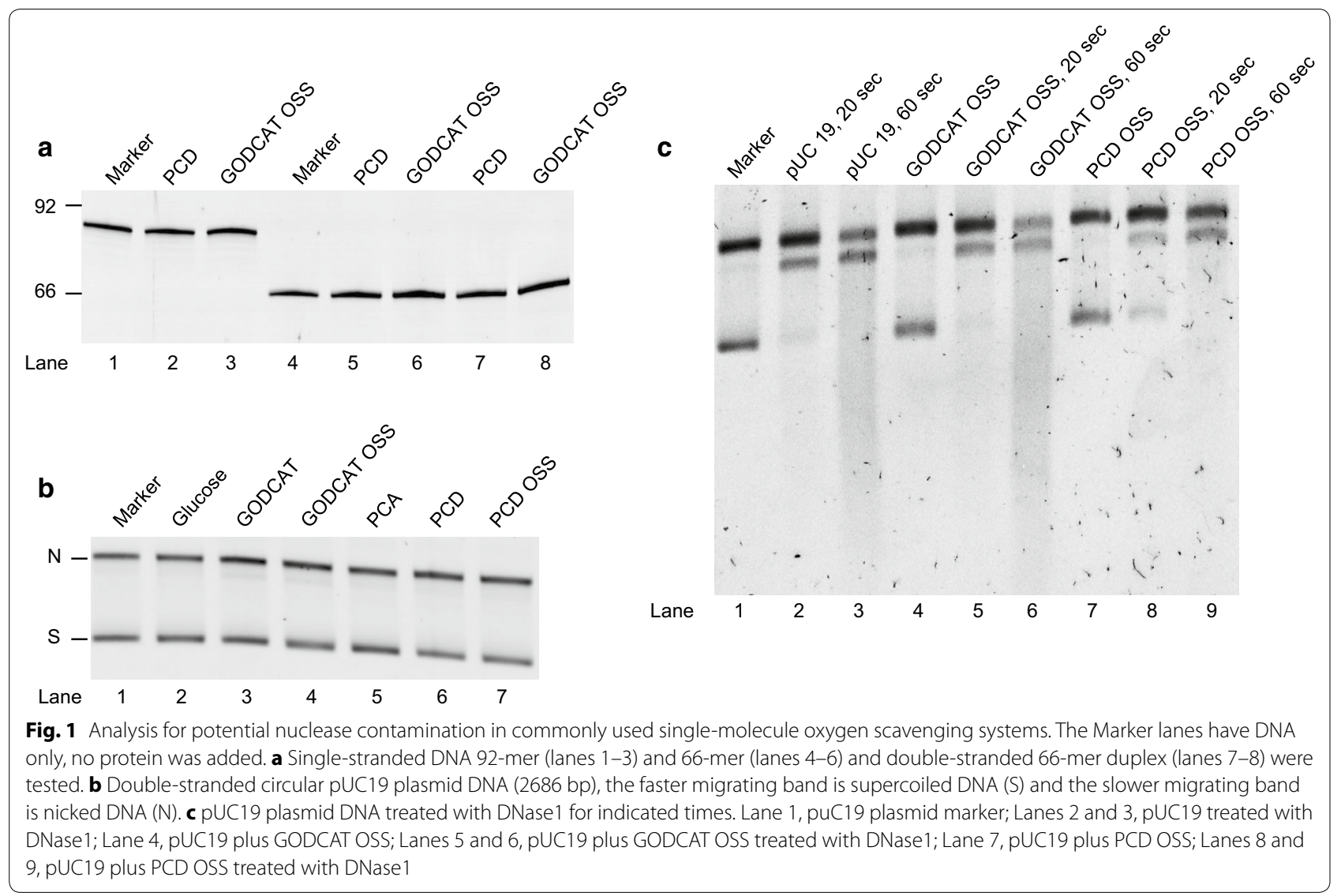

of PCD with stabilizer), $5 \mathrm{mM}$ PCA, 35 units/mL glucose oxidase (GOD), 62,500 units/mL catalase (CAT) and $1 \%$ D-Glucose. GODCAT OSS includes glucose oxidase, catalase and D-Glucose while PCD OSS contains both PCD and PCA. For experiments with DNase1 (Turbo DNase Ambion, Life Technologies), reactions were performed at a final concentration of $0.4 \mathrm{U}$ in $100 \mu \mathrm{L}$ and stopped at 20 and $60 \mathrm{~s}$. Reactions were tested in duplicate with the same buffer conditions as Senavirathne et al. [1]. containing $50 \mathrm{mM}$ Tris- $\mathrm{HCl} \mathrm{pH} \mathrm{7.5,} 100 \mathrm{mM} \mathrm{NaCl}, 5 \mathrm{mM}$ $\mathrm{MgCl}_{2}$ and $0.1 \mathrm{mM} \mathrm{DTT}$ at $22{ }^{\circ} \mathrm{C}$ for $40 \mathrm{~min}$. Following each reaction, linear DNA was separated on a $15 \%$ polyacrylamide gel and plasmid DNA on a $1 \%$ agarose gel. SYBR gold was used for nucleic acid staining in addition to direct visualization with DNA containing Cy3. Gels were visualized on a FUJIFILM FLA-5100 instrument.

\section{Results and discussion}

Linear, single- and double-stranded, and plasmid DNA substrates were tested for nuclease contamination in oxygen scavenging systems that are routinely used during single-molecule imaging. The nuclease assay consisted of incubating the OSS with the respective DNA and running on a polyacrylamide, in the case of linear DNA, and an agarose gel in the case of plasmid DNA. Using standard protocols [2-4], we did not observe any DNA degradation on all DNA substrates tested under the same buffer conditions used by Senavirathne et al. [1] Fig. 1.

We have compared our reagent sources to those in the previous manuscript by Senavirathne et al. Most of the reagents come from the same source and lot number (Table 1), suggesting that potential contamination from the commercial source may not provide an answer for the degradation observed previously by Senavirathne et al.

Additionally, we have compared our experimental conditions to those in the manuscript by Senavirathne et al. (Table 2). While most concentrations used are similar, there are a few exceptions, which are outlined in Table 2. It is important to note that the largest amount of degradation observed by Senavirathne et al. was for the catalase enzyme. For this, we used a larger concentration of catalase in comparison to the previous study and still did not observe any nucleic acid degradation in our assays.

These findings are important to rule out the potential for nuclease contamination in the common oxygen scavenging systems used in single-molecule imaging [1]. We feel it is of value to reassure the wider scientific community that we do not observe nucleic acid degradation 
Table 1 List of materials and providers used in this work

\begin{tabular}{|c|c|c|c|c|c|c|}
\hline \multirow[t]{2}{*}{ Product } & \multicolumn{3}{|c|}{ Senavirathne et al. } & \multicolumn{3}{|c|}{ Gahlon et al. } \\
\hline & Supplier & Cat. no. & Lot no. & Supplier & Cat. no. & Lot no. \\
\hline PCD & Sigma & P8279-25UN & SLBL 454 IV & Sigma & P8279-25UN & SLBL $454 \mathrm{IV}$ \\
\hline PCA & $N P^{a}$ & & & Sigma & 37580-100G-F & $\mathrm{BCBH} 2769 \mathrm{~V}$ \\
\hline GOD & Sigma & G2133-10KV & BCBP8730V & Sigma & G2133-10KV & BCBP8730V \\
\hline Catalase & Sigma & C9322-1G & SLBG1321V & Sigma ${ }^{b}$ & C100-50MG & SLBH8572V \\
\hline Glucose & $N P^{a}$ & & & Sigma & G8270-5KG & SZBE0450V \\
\hline
\end{tabular}

${ }^{a}$ Reagent source not specified by Senavirathne et al.

b We used the same provider, but purchased in lower quantities (50 mg vs. $1 \mathrm{~g}$ )

Table 2 List of reagents used in this work

\begin{tabular}{lll}
\hline Reagent & Senavirathne et al. & Gahlon et al. \\
\hline Buffer & $50 \mathrm{mM}$ Tris-HCl & $50 \mathrm{mM}$ Tris- $\mathrm{HCl}$ \\
$\mathrm{pH}$ & 7.5 & 7.5 \\
$\mathrm{NaCl}(\mathrm{mM})$ & 100 & 100 \\
$\mathrm{MgCl}(\mathrm{mM})$ & 5 & 5 \\
$\mathrm{DTT}(\mathrm{mM})$ & 0.1 & 0.1 \\
Incubation time $(\mathrm{min})$ & 40 & 40 \\
Temperature $\left({ }^{\circ} \mathrm{C}\right)$ & 22 & 22 \\
PCA $(\mathrm{mM})$ & 5 & 5 \\
PCD & $0.21 \mathrm{U} / \mathrm{mL}$ & $60 \mathrm{nM}^{\mathrm{a}}$ \\
Glucose, $(\%)$ & 0.8 & 1 \\
GOD $(\mathrm{U} / \mathrm{mL})$ & 165 & 35 \\
Catalase $(\mathrm{U} / \mathrm{mL})$ & 2170 & 62,500 \\
Linear DNA & $10 \mathrm{ng} / \mu \mathrm{L}^{\mathrm{b}}$ & $100 \mathrm{nM}$ \\
Plasmid $(\mathrm{ng} / \mu \mathrm{L})$ & 10 & 10 \\
\hline
\end{tabular}

a We used conditions comparable to their highest concentration

b Concentration varies from $~ 350$ to $600 \mathrm{nM}$ depending on construct size

with our samples and that alternative explanations may account for the previously reported DNA degradation [1]. For example, while the most significant degradation observed in the previous work [1] was for the pBS SK (-) plasmid, in our hands we did not observe any degradation with the pUC19 plasmid DNA (Fig. 1b). This discrepancy could be due to a restriction enzyme contamination rather than a nuclease, in this instance the observed degradation would be sequence specific. If this is true, experiments involving plasmid DNA or sequences with restriction sites may require prior removal of any contaminant enzymes in the oxygen scavenging systems. Alternatively, the nuclease contamination could be an isolated set of data either from contamination introduced during the preparation of the enzyme-based oxygen scavenging samples or contamination directly from the commercial sources. However, the PCD and GOD enzymes tested by Senavirathne et al. and by us were from the same supplier with the same lot number (Table 1), suggesting that that commercial source may not provide a complete answer. Therefore, we encourage labs utilizing oxygen-scavenging systems to test for contaminants that might degrade DNA or RNA in their own experiments to mitigate any experimental artifacts.

\section{Limitations}

Further DNA substrates should be tested with both oxygen scavenging systems (i.e. glucose oxidase/catalase and the PCA PCD system). It would also be good to test in a systematic way other nucleic acid substrates to asses if DNA sequence may be important.

\section{Abbreviations \\ OSS: oxygen scavenging system; PCD: protocatechuate-3,4-dioxygenase; PCA: protocatechuic acid; GODCAT: glucose-coupled glucose oxidase/catalase.}

\section{Authors' contributions}

HLG and DR designed the experiments. HLG performed the experiments and analyzed the data. PPD performed the experiments with DNase1 and helped analyze the data. HLG and DR wrote the correspondence. All authors read and approved the final manuscript.

\section{Author details}

${ }^{1}$ Molecular Virology, Department of Medicine, Imperial College London, Du Cane Road, London W12 ONN, UK. ${ }^{2}$ Single Molecule Imaging Group, MRC London Institute of Medical Sciences, Du Cane Road, London W12 0NN, UK.

\section{Acknowledgements}

We would like to thank Adam Cawte for helpful discussions and feedback.

Competing interests

The authors declare that they have no competing interests.

\section{Availability of data and materials}

All data are contained within the manuscript. Materials are available upon request.

\section{Consent for publication}

Not applicable.

\section{Ethics approval and consent to participate} Not applicable.

\section{Funding}

This work was supported by the MRC London Institute of Medical Sciences (RCUK MC-A658-5TY10) and a start-up grant from Imperial College London. 
H.L.G. is a fellow of the Swiss National Science Foundation and the Marie Sklodowska-Curie Individual Fellowship.

\section{Publisher's Note}

Springer Nature remains neutral with regard to jurisdictional claims in published maps and institutional affiliations.

Received: 31 August 2017 Accepted: 14 November 2017

Published online: 21 November 2017

\section{References}

1. Senavirathne G, Liu J, Lopez MA Jr, Hanne J, Martin-Lopez J, Lee JB, Yoder KE, Fishel R. Widespread nuclease contamination in commonly used oxygen-scavenging systems. Nat Methods. 2015;12:901-2.
2. Lamichhane R, Solem A, Black W, Rueda D. Single-molecule FRET of protein-nucleic acid and protein-protein complexes: surface passivation and immobilization. Methods. 2010;52:192-200.

3. Senavirathne G, Bertram JG, Jaszczur M, Chaurasiya K, Pham P, Mak C, Goodman MF, Rueda D. Activation-induced deoxycytidine deaminase (AID) co-transcriptional scanning at single-molecule resolution. Nat Commun. 2015;6:10209.

4. Aitken CE, Marshall RA, Puglisi JD. An oxygen scavenging system for improvement of dye stability in single-molecule fluorescence experiments. Biophys J. 2008;94:1826-35.

\section{Submit your next manuscript to BioMed Central} and we will help you at every step:

- We accept pre-submission inquiries

- Our selector tool helps you to find the most relevant journal

- We provide round the clock customer support

- Convenient online submission

- Thorough peer review

- Inclusion in PubMed and all major indexing services

- Maximum visibility for your research

Submit your manuscript at www.biomedcentral com/submit 